\title{
Manfaat Kajian Gerabah Masa Lalu Bagi Pengembangan Kerajinan Tembikar Sebagai Penunjang Industri Pariwisata
}

\section{Sumijati Atmosudiro}

Keywords: pottery, cultural resource management, development, tourism, modelling

\section{How to Cite:}

Atmosudiro, S. (1998). Manfaat Kajian Gerabah Masa Lalu Bagi Pengembangan Kerajinan Tembikar Sebagai Penunjang Industri Pariwisata. Berkala Arkeologi, 18(2), 1-11. https://doi.org/10.30883/jba.v18i2.779



\section{(i)(2) (2)}

This work is licensed under a Creative Commons Attribution-NonCommercial-ShareAlike 4.0 International License. 


\title{
MANFAAT KAJIAN GERABAH MASA LALU \\ BAGI PENGEMBANGAN KERAJINAN TEMBIKAR \\ SEBAGAI PENUNJANG INDUSTRI PARIWISATA*
}

\author{
Sumijati As. \\ (Fakultas Sastra UGM)
}

\section{Latar Belakang Masalah}

Gerabah atau tembikar sebagai budaya materi merupakan bukti usaha manusia untuk melengkapi kebutuhan hidupnya terutama kebutuhan akan wadah. Di Indonesia gerabah berbentuk wadah berkembang pada masa bercocok tanam kira-kira 2500 1500 tahun sebelum Masehi. Dalam kehidupan bercocok tanam dan menetap dituntut peningkatan keperluan hidup, baik keperluan yang digunakan untuk bercocok tanam maupun kebutuhan yang berhubungan dengan wadah, misalnya untuk tempat makanan dan air atau untuk memasak. Sehubungan dengan hal itu, ketrampilan membuat gerabah disejajarkan dengan kemahiran mengupam alat-alat batu, misalnya kapak persegi yakni salah satu peralatan yang digunakan dalam aktivitas bercocok tanam.

Dalam kehidupan masa lampau penggunaan gerabah sebagai peralatan hidup tersebar luas di berbagai wilayah di dunia baik di Eropa, Amerika, Asia, Australia, maupun di Kepulauan Pasifik. Di Indonesia hal itu dibuktikan dengan temuan gerabah baik utuh maupun pecahan dalam jumlah banyak di beberapa situs, baik situs dari Masa Prasejarah, Masa Klasik, maupun Masa Islam. Di antara situs-situs ini adalah : Kalumpang dan Melolo (Masa Prascjarah), Sambisari dan Trowulan (Masa Klasik), dan Banten serta Biting (Masa Islam).

Bila ditinjau dari sifat situsnya maka situs-situs tersebut adalah situs pemukiman, situs knbur, dan situs pemujaan. Berdasarkan hal itu maka dapat diperoleh gambaran bahwa gerabah masa lampau erat kaitannya dengan beberapa aspek kehidupan, di antaranya adalah aspek sosial-ekonomi dan religi. Salah satu faktor yang menyebabkan gerabah banyak ditemukan di situs-situs arkeologi adalah sifat gerabah yang tahan dari pelapukan. sehingga walaupun mudah pecah akan tetapi tidak hancur. Oleh karena itu, temuan gerabah pada umumnya berbentuk fragmen atau lebih lazim disebut dengan istilah kereweng.

Ide pembuatan gerabah merupakan keberhasilan manusia dalam mewujudkan pengalaman empirisnya tentang sifat-sifat tanah liat yang mudah dibentuk pada saat masih lembek. dan akan menjadi keras bila kena panas serta tetap keras walaupun

- Makalah ini pernah disampaikan dalam Simposium Regional Sehari : "Konstribusi Kajian Arkeologi Bagi Kehidupan Masa Kini dan Masa Datang", di IKIP Malang, 16 September 1998 
telah dingin. Selain itu, tanah liat juga mempunyai sifat yang mudah licin bila kena air dan licat bila basah. Sifat unik tersebut disebabkan oleh karena tanah liat adalah sejenis tanah (TL) yang memiliki butiran-butiran yang sangat halus bergaris tengah di bawah $0.01 \mathrm{~mm}$. Butiran berbentuk gepeng, datar tipis seperti kepingan kaca yang berukuran kecil. Oleh karena itu, keberhasilan manusia menciptakan benda-benda tanah liat atau gerabah dapat memberi gambaran bahwa manusia masa lalu telah mampu beradaptasi serta arif terhadap alam lingkungannya.

Dari segi teknologi, pembuatan gerabah dapat dikatagorikan sebagai suatu kemajuan dalam peradapan manusia karena dalam pembuatan gerabah diperlukan proses yang lebih rumit bila dibandingkan dengan pembuatan alat-alat dari batu. Kerumitan itu antara lain tampak dalam proses pencampuran bahan, cara pembentukan, dan proses pembakaran. Proses pencampuran dan pembakaran tidak dikenal dalam pembuatan alat-alat dari batu, sedangkan proses pembentukannyapun berbeda karena pembentukan gerabah termasuk dalam teknologi penambahan, sedangkan pembentukan alat-alat batu merupakan teknologi pengurangan.

Gerabah dalam seni rupa dimasukkan sebagai hasil seni kriya karena proses pembuatannya lebih menekankan pada kerja dan ketrampilan tangan. Bahkan pembuatan gerabah oleh Gearheart (1986) dianggap sebagai seni api karena dalam proses pembuatannya diakhiri dengan pembakaran yang amat menentukan hasil akhir produksinya. Akibat pembakaran, gerabah menjadi lebih ringan bila dibandingkan dengan sebelum dibakar dan mencapai bentuk akhir dengan warna yang berbeda dengan bahan dasarnya. Dengan demikian, api telah digunakan secara intensif dalam teknologi dan menjadi salah satu faktor penggerak kemajuannya (Sumijati, 1994).

Uraian di atas dapat memberi gambaran bahwa gerabah adalah salah satu hasil seni kriya dari bahan tanah liat yang dibakar. Adapun temperatur pembakarannya berkisar antara $350^{\circ}-1000^{\circ} \mathrm{C}$. Sebagai benda buatan manusia dimungkinkan pada gerabah melekat beberapa aspek perilaku pembuat dan pemakainya. Namun demikian, jarang manusia yang tertarik untuk mengungkapkan dan mengetahui hal-hal yang berkaitan dengannya walaupun dalam kehidupan sehari-hari benda tersebut dilihat, dipakai bahkan sering dikagumi. Sehubungan dengan itu, Matson (1965) mengemukakan bahwa dari gerabah masa lampau dapat diungkap beberapa aspek kehidupan, di antaranya adalah : teknologi pembuatannya, seni, ekologi, dan periodisasinya. Pendapat tersebut diperkuat oleh Shepart (1965) yang mengemukakan bahwa dari gerabah dapat diketahui beberapa aktivitas manusia, misalnya aktivitas yang berhubungan dengan sosial-ekonomi dan religi. Pendapat yang senada dikemukakan pula oleh Solheim II (1965) yang menyatakan bahwa dengan mempelajari gerabah dapat direkonstruksi pola tingkah laku pendukungnya. 
Beranjak dari pendapat para sarjana di atas dan sejalan dengan perkembangan arkeologi Indonesia maka minat penelitian arkeologi tidak hanya difokuskan pada tinggalan-tinggalan yang monumental, akan tetapi ditujukan pula pada tinggalan nonmonumental seperti halnya temuan gerabah. Hal itu dibuktikan dengan banyaknya kajian tentang gerabah baik dalam bentuk artikel, skripsi, tesis maupun disertasi. Akibat banyaknya penelitian gerabah tersebut muncul masalah yang perlu dipecahkan terutama masalah manfaat kajian gerabah masa lampau dalam kaitannya dengan pengembangan kerajinan gerabah masa kini. Pada gilirannya hasil pengembangan itu dapat digunakan sebagai salah satu aset yang menunjang industri pariwisata. Agar dapat memecahkan masalah tersebut maka perlu dikemukakan secara garis besar hasil kajian gerabah masa lalu dan gerabah tradisional.

\section{Kajian Gerabah Masa Lalu dan Gerabah Tradisional}

Beberapa kajian terhadap gerabah masa lalu menunjukkan bahwa aspek teknologi merupakan topik yang banyak menarik perhatian para peneliti. Hal itu terjadi karena dari data fisik gerabah tercermin jejak-jejak teknologi, walaupun sangat terbatas sesuai dengan kondisi data arkeologi yang sangat fragmentaris. Selain itu, aspek yang juga mendapat perhatian para ahli adalah bentuk dan jenis gerabah karena kedua aspek tersebut pada gilirannya dapat mengungkapkan fungsi dari suatu jenis gerabah. Kedua aspek itu dapat diungkap karena temuan gerabah biasanya berupa bagianbagian tertentu dari suatu wadah, misalnya bagian : tepian, leher, karinasi, serat, atau dasar.

Hasil kajian terhadap teknologi pembuatan gerabah pada umumnya tidak dapat mengungkap seluruh proses pembuatan, mengingat bahwa pembuatan gerabah termasuk dalam teknologi penambahan yang memiliki tahapan-tahapan kerja yang selalu berurutan dan saling berkaitan. Tahapan-tahapan itu adalah: pengadaan dan pengolahan (pencampuran) bahan, proses dan teknik pembentukan, dan pembakaran. Dalam proses pengadaan bahan dan pengolahan bahan biasanya hanya dapat diungkap mengenai bahan baku yang digunakan dan bahan campuran (tempernya). Bahan campuran terscbut dapat berupa pasir halus, sedang, kasar, atau fragmen gerabah dan atau cangkang karang yang dihaluskan. Dari proses pembakaran hanya dapat diketahui suhu pembakaran serta proses oksidasi dan reduksinya. Dari hasil-hasil itu dapat diketahui tentang kualitas pembakarannya serta lokasi yang digunakan sebagai tempat pembakaran.

Aspek perilaku yang lebih banyak dapat diungkap adalah perilaku yang berhubungan dengan teknik pembentukan dan penyelesaian permukaan. Berdasarkan hasil kajian terhadap teknik pembentukan dapat diketahui bahwa pada awal pemunculannya gerabah dibuat dengan cara yang sangat sederhana. Teknik yang digunakan dikenal 
dengan istilah hand-made yakni suatu teknik pembentukan gerabah yang belum menggunakan alat. Dengan demikian, semua proses pembentukannya hanya dilakukan dengan tangan. Kemudian teknik itu dipadukan dengan teknik tatap-pelandas (paddleanvil). Sejalan dengan kemajuan pemikiran manusia dalam mengembangkan teknologi yakni dengan munculnya kemahiran melebur dan menuang logam, maka berkembang pula teknik pembentukan gerabah. Teknik yang digunakan saat itu adalah teknik tatap-pelandas yang dipadukan dengan roda putar (potter's wheel).

Berdasarkan data arkeologis diperoleh bukti bahwa teknik tatap-pelandas yang dipadukan dengan roda putar terus digunakan pada masa berkembangnya pengaruh agama Hindu dan Budha (Masa Klasik) dan juga dalam masa berkembangnya agama Islam (Masa Islam). Bahkan data etnografis menunjukkan bahwa teknik tersebut tetap digunakan oleh perajin gerabah tradisional. Sedangkan dari penyelesaian permukaan sebagai tahap akhir sebelum pembakaran dapat diungkap cara-cara untuk menyelesaikan permukaan gerabah. Di antara cara itu adalah diberi hiasan, dioles (slip), dan diupam. Ketiga cara tersebut dimaksudkan untuk memperindah permukaan. Selain itu, slip dan upam dapat memperkecil dan merapatkan porositas gerabah.

Pada mulanya pola-pola hias yang diterapkan pada permukaan gerabah hanya berupa garis yang membentuk anyaman keranjang dan duri ikan dengan teknik tekan. Kemudian pola-pola hias yang diterapkan makin banyak variasinya dengan teknik yang bermacam pula. Teknik-teknik hias yang diterapkan di antaranya adalah teknik gores, teknik tekan, teknik cungkil, dan teknik iris serta teknik tempel. Pola-pola hias yang dibentuk dengan teknik gores adalah pola geometris, misalnya tumpal, lingkaran-lingkaran memusat, belah ketupat, garis-garis horisontal, dan vertikal, sedangkan teknik tekan dapat menghasilkan pola-pola yang sesuai dengan alat yang digunakan,misalnya cangkang kerang, kuku atau jari-jari. Teknik tekau dapat pula dibentuk melalui tatap yang diukir, misalnya pola jala dan pola-pola anyaman. Teknik cungkil dan iris dapat membentuk pola-pola segitiga, sedangkan teknik tusuk dapat membentuk pola titik-titik

Selain pola-pola hias tersebut di atas, terdapat pula pola hias kedok atau topeng yang diterapkan pada leher atau pundak kendi. Pola hias tersebut dibentuk dari unsur-unsur geometris misalnya mata dibentuk dari bulatan, mulut dari belah ketupat. Bentukbentuk bulatan juga digunakan untuk menggambarkan telinga dan hidung. (Heekeren, 1965; Sumijati, 1994)

Pada masa berkembangnya agama Hindu Budha teknik dan pola-pola hias masa sebelumnya tetap digunakan dan pada masa Majapahit pengetrapan pola-pola hias pada gerabah mencapai puncak kejayaannya. Teknik-teknik gores, tempel, dan tekan dipadukan sehingga menghasilkan pola-pola hias yang indah dan kompleks. Aspek lain yang menonjol pada gerabah Majapahit adalah banyaknya variasi dan keunikan 
bentuk gerabah sehingga gerabah Majapahit mampu dinyatakan sebagai karya seni kriya yang memiliki nilai seni yang tinggi.

Pada awal kemunculannya, jenis dan bentuk gerabah yang diproduksi tidak banyak variasinya. Jenis-jenis gerabah itu pada umumnya mempunyai bentuk bulat baik pada bagian badan maupun bagian dasarnya dengan bentuk tepian yang sederhana. Dari kesederhanaan dan sedikitnya variasi jenis-jenis gerabah yang diproduksi dapat memberi pengertian bahwa saat itu yang dipentingkan adalah pemenuhan kebutuhan akan wadah. Seiring dengan kemajuan teknik pembentukannya maka variasi jenis dan bentuk gerabahnyapun berkembang misalnya adanya gerabah yang berkarinasi, munculnya jenis cawan berkaki (pedupaan), kendi, tempayan, dan gerabah-gerabah yang berukuran kecil (mini). Variasi jenis dan bentuk gerabah tampaknya tidak dapat dipisahkan dari upaya manusia dalam memenuhi kebutuhan hidup baik untuk keperluan sehari-hari maupun keperluan yang berhubungan dengan religi.

Gerabah yang digunakan untuk keperluan yang berhubungan dengan religi di antaranya adalah tempayan, periuk, cawan berdasar bulat atau yang berkaki, dan gerabah yang berukuran kecil (gerabah mini). Tempayan digunakan sebagai wadah mayat, sedangkan jenis-jenis gerabah yang lain digunakan untuk peralatan upacara. Kubur tempayan antara lain ditemukan di Situs Plawangan (Sukendar, 1981) dan Gilimanuk (Soejono, 1971), sedangkan gerabah sebagai bekal kubur antara lain ditemukan pula di kedua situs tersebut. Perkembangan fungsi terjadi pula pada masa berkembangnya agama Hindu-Budha dibuktikan dengan gerabah jenis periuk yang digunakan sebagai peripih (Soekmono, 1974), seperti yang ditemukan di Candi Gampingan dan Candi Bogang (Sugihardi, 1994). Adapun gerabah yang digunakan sebagai peralatan upacara biasanya dari jenis periuk, cawan, pedupaan seperti yang ditemukan di situs-situs percandian, misalnya Candi Borobudur dan Candi Sambisari (Helmi, 1983).

Puncak perkembangan aspek fungsi gerabah terjadi pada masa Majapahit yang ditandai dengan munculnya jenis-jenis gerabah yang digunakan sebagai benda praktis yang sekaligus berfungsi sebagai benda dekoratif. Di antara benda-benda itu adalah : vas-vas bunga, wuwungan rumah, tempat menabung uang (celengan), dan kendi. Agar misi sebagai benda dekoratif terpenuhi maka jenis-jenis gerabah tersebut mempunyai bentuk yang unik atau diberi hiasan yang bagus.

Kondisi puncak fungsi gerabah dan pengetrapan pola-pola hias menurun pada masa berkembangnya agama Islam. Bentuk-bentuk gerabah pada masa itu kembali ke bentuk sederhana dan jarang yang dilengkapi dengan pola-pola hias yang raya. Gerabah pada masa itu tampaknya lebih banyak digunakan untuk memenuhi kebutuhan sehari-hari. Salah satu jenis gerabah yang dimungkinkan sebagai peralatan upacara di antaranya hanya pedupaan, sedangkan peralatan yang lain seperti piring 
atau piring panjang digantikan oleh keramik Cina. Hal seperti itu terjadi di Keraton Surakarta dan Yogyakarta yang menggunakan piring Cina untuk upacara-upacara. Di Keraton Surakarta piring itu dinamakan Kyai Blowong, sedangkan di Keraton Yogyakarta piring itu dinamakan Nyai Blowong.

Selain aspek-aspek tersebut di atas, kajian gerabah masa lalu dapat pula memberi gambaran bahwa masyarakat pembuat dan pemakai gerabah telah pula mengadakan komunikasi. Perilaku tersebut dapat diketahui dari adanya persamaan dan perbedaan gerabah di beberapa situs. Data tersebut dapat menunjukkan bahwa pendukung gerabah di suatu situs tidak hanya berkomunikasi dengan satu produsen dalam upaya pemenuhan kebutuhan gerabah. Terjadinya komunikasi antara produsen dan konsumen disebabkan oleh terbatasnya kemampuan individu atau kelompok individu dalam upaya memenuhi kebutuhan hidupnya.

Dari uraian di atas dapat ditarik pengertian bahwa keberadaan gerabah dalam kehidupan masa lampau mengalami dinamika, sejalan dengan sifat dinamis manusia dalam upaya memenuhi kebutuhan terhadap suatu benda yang tidak dimilikinya. Oleh karena itu, pada masa kini beberapa kelompok etnis di Indonesia masih bertahan menjadi perajin gerabah tradisional karena beberapa individu atau kelompok individu tetap memerlukan gerabah sebagai suatu benda keperluan hidupnya. Namun demikian, perajin gerabah tradisional makin tergusur dan tersisih terutama sejak plastik mendominasi bahan pembuatan peralatan hidup.

Penelitian terhadap perajin gerabah tradisional di beberapa kelompok etnis baik di Pulau Jawa maupun di luar Jawa dapat diketahui bahwa teknologi dalam pembuatan gerabah tetap menggunakan teknologi masa lalu. Perajin gerabah tradisional di pulau Jawa pada umumnya menggunakan teknik roda putar (perbot) yang dipadukan dengan tatap-pelandas, sedangkan perajin di luar Jawa banyak yang menggunakan teknik tangan yang dipadukan dengan tatap-pelandas (Sumijati, 1972, 1980, 1985, 1994). Di samping teknik pembentukan, penyelesaian permukaan dan pembakarannya juga menunjukkan persamaan dengan gerabah masa lalu. Penyelesaian permukaan yang banyak diterapkan adalah slip dan upam, sedangkan pemberian pola-pola hias jarang dilakukan, sedangkan pembakaran gerabah dilakukan di tempat-tempat terbuka dengan bahan-bahan berupa kayu, jerami, dan rumput-rumputan. Cara pembakaran tersebut biasanya menghasilkan temperatur yang kurang dari $1000^{\circ} \mathrm{C}$, seperti halnya temperatur pembakaran gerabah masa lampau.

Data tersebut dapat memberi gambaran bahwa teknologi pembuatan gerabah tradisional dan hasil produksinya merupakan hasil budaya warisan nenek moyang yang perlu dilestarikan. Oleh karena itu, sangat disayangkan apabila warisan budaya itu musnah dilanda arus modernisasi. Untuk menanggulangi hal itu perlu dipikirkan 
langkah-langkah untuk mengatasinya, di antaranya pengembangan kerajinan gerabah tradisional.

\section{Pengembangan Kerajinan Gerabah Tradisional}

Terciptanya barang-barang gerabah paling tidak perlu didukung oleh empat faktor, yakni : kebutuhan, tersedianya bahan, penguasaan teknologi, dan daya kreasi perajin (Subroto, 1987). Faktor kebutuhan tidak dapat terpenuhi apabila tidak tersedia bahan bakunya, demikian pula tersedianya bahan baku perlu disertai dengan penguasaan dan daya kreasi perajinnya. Dengan demikian, antara faktor yang satu dengan faktor yang lain saling mendukung. Oleh karena itu, keempat faktor tersebut perlu pula diperhatikan bila akan mengembangkan kerajinan gerabah tradisional.

Data di lapangan menunjukkan bahwa kerajinan gerabah tradisional ditemukan di beberapa daerah di Indonesia. Kondisi kerajinan gerabah di beberapa daerah itu ada yang tetap hidup dan terkenal, tetapi ada pula yang tidak terkenal dan bahkan ada yang punah. Faktor yang menyebabkan punałnya kerajinan gerabah antara lain menyangkut sumber daya manusianya. Pada masa sekarang sangat jarang generasi yang mau atau tertarik mewarisi keahlian keluarganya sebagai perajin gerabah.

Anak-anak muda lebih tertarik dan memilih menjadi buruh atau menekuni pekerjaan lain daripada membuat gerabah yang kotor. Akibatnya, pada saat ini perajin gerabah hanya orang-orang tua yang jumlahnya makin lama makin berkurang. Faktor lain yang juga mempengaruhi punahnya perajin gerabah tradisional adalah menipisnya permintaan pasar yang disebabkan kurangnya konsumen yang memerlukan gerabah.

Kurangnya sumber daya manusia yang berminat menjadi perajin gerabah tradisional menimbulkan kurangnya faktor penguasaan teknologi, sedangkan menipisnya permintaan dapat diartikan kurangnya faktor kebutuhan. Berkurangnya dua faktor tersebut bila dibiarkan dapat berakibat kerajinan gerabah tradisional tidak dapat berkembang. Kenyataan itu diperkuat oleh kondisi kerajinan gerabah tradisional yang tetap survive dan berkembang sehingga terkenal sampai di manca negara seperti yang terjadi pada perajin gerabah Kasongan.

Perajin gerabah tradisional di Kasongan dalam mengembangkan hasil produksinya tampak memperhatikan empat faktor pendukung berkembangnya benda-benda gerabah. Dalam faktor kebutuhan, perajin gerabah Kasongan berupaya menciptakan jenis-jenis gerabah yang diminati konsumen. Untuk itu, perajin gerabah Kasongan tidak hanya membuat gerabah sebagai peralatan rumah tangga, tetapi juga membuat berbagai jenis gerabah yang bagus sehingga dapat digunakan sebagai benda praktis, 
dekoratif, atau sebagai cindera mata. Benda-benda cindera mata biasanya berukuran kecil.

Dalam faktor bahan, perajin gerabah Kasongan berupaya mencari bahan baku yang sesuai dengan jenis gerabah yang diproduksi. Tidak jarang pula perajin gerabah Kasongan mendatangkan bahan dasar dari luar, agar bahan baku cukup tersedia dan berkualitas baik. Sedangkan dalam faktor penguasaan teknologi, perajin gerabah Kasongan tetap menggunakan teknologi yang telah dikuasai secara turun-temurun, yakni teknik roda putar yang dipadukan dengan tatap pelandas, sedangkan proses pembakarannya ada yang dilakukan di tungku, terutama untuk jenis gerabah non rumah tangga.

Selain itu pelaku / perajin gerabahnya tidak terbatas pada kaum perempuan, akan tetapi para laki-laki pun tertarik dalam profesi ini. Dalam hal ini tampak terjadi pembagian pekerjaan yang mengarah pada spesialisasi. Perajin perempuan tetap memproduksi gerabah untuk keperluan rumah tangga, misalnya periuk, tempayan, pot, dan anglo. sedangkan perajin laki-laki lebih tertarik pada pembuatan benda-benda dekoratif dan cindera mata. Namun demikian, sering pula terjadi kerja sama antara perajin perempuan dan laki-laki dalam menciptakan suatu jenis gerabah. Perajin perempuan bertugas membuat bentuk bendanya, sedangkan perajin laki-laki yang memperindah dan memberi pola-pola hias.

Teknik hias masa lalu misalnya teknik gores, tekan, dan tempel tetap digunakan, akan tetapi dari teknik-teknik hias tersebut teknik tempel paling banyak digunakan. Dengan demikian, kerajinan gerabah tradisional di Kasongan dapat mengatasi kendala yang menyangkut menyusutnya sumber daya manusia yang menguasai teknologi pembuatan gerabah.

Pengembangan kerajinan gerabah tradisional Kasongan tampak pula dalam faktor daya kreasi perajinnya. Hal tersebut ditunjukkan dengan munculnya bermacam jenis dan bentuk gerabah yang unik. Dalam kasus itu, tidak jarang bahwa bentuk unik tersebut muncul dari gerabah rumah tangga yang diberi sentuhan gaya kreasi para perajinnya schingga tercipta suatu jenis gerabah yang bagus dan menarik. Gaya kreasi perajin gerabah Kasongan tampaknya merupakan perpaduan dari bakat alam yang dimiliki para perajin dan pengetahuan tambahan yang diberikan oleh senimanseniman kondang, misalnya Saptohoedojo dan Larasati Soelaiman.

Upaya-upaya di atas menyebabkan hasil kerajinan gerabah Kasongan banyak diminati konsumen baik dalam maupun luar negeri. Dengan demikian, pengembangan kerajinan gerabah Kasongan merupakan salah satu cara untuk melestarikan hasil budaya bangsa. Akibat lain yang muncul dari pengembangan itu adalah terbentuknya Desa Kasongan menjadi sentra industri gerabah yang penghasilannya dapat 
meningkatkan taraf hidup perajinnya. Di sisi lain, dalam pengembangan itu sering muncul benda-benda yang lepas dari budaya setempat, misalnya patung-patung primitif bergaya Asmat atau gaya-gaya lain yang sesuai dengan permintaan pasar. Kondisi tersebut bila dibiarkan akan muncul dampak negatif yakni hilangnya ciri budaya setempat.

Pengembangan kerajinan gerabah tradisional seperti yang terjadi di Kasongan, tampaknya dapat pula dilakukan oleh perajin-perajin gerabah yang lain. Salah satu contoh adalah perajin gerabah di daerah Pundong (Bantul), meskipun pengembangan itu baru difokuskan pada gerabah rumah tangga dan cindera mata perajin Pundong ada yang didistribusikan melalui sentra industri gerabah Kasongan. Dengan demikian, kerajinan gerabah Kasongan akan lebih dikenal dari daerah yang memproduksi.

\section{Penutup}

Paparan di atas dapat memberi gambaran bahwa kajian gerabah masa lalu dapat mengungkapkan beberapa aspek kehidupan baik pembuat maupun pemakainya. Selain itu. dalam perjalanan sejarahnya kerajinan gerabah mengalami dinamika yang sejalan dengan sifat dinamis manusia pendukungnya.

Manfaat lain yang dapat dipetik dari kajian gerabah masa lalu adalah kearifan manusia terhadap lingkungannya sehingga memunculkan ide membuat benda kebutuhan hidup dengan bahan tanah liat. Dengan demikian, manusia masa lalu telah mempertimbangkan faktor kebutuhan, tersedianya bahan, penguasaan teknologi, dan daya kreasi. Ke-empat faktor tersebut tampaknya tetap relevan dalam pengembangan gerabah tradisional di Kasongan.

Akibat berhasilnya pengembangan itu, Kasongan menjadi sentra industri gerabah yang hasilnya diminati konsumen baik dalam maupun luar negeri. Oleh karena itu, kerajinan gerabah tradisional bila berhasil dikembangkan dapat pula menjadi aset wisata yang dapat menunjang industri pariwisata.

Langkah pengembangan kerajinan gerabah Kasongan dapat digunakan sebagai salah satu model pengembangan kerajinan gerabah tradisional di daerah lain dengan menghilangkan dampak negatifnya. Di antaranya adalah hilangnya ciri budaya lokal. Oleh karena itu, dalam pengembangan kerajinan gerabah tradisional perlu menggali hasil budaya setempat yang dapat divisualisasikan menjadi hasil seni kriya dari tanah liat.

Pengembangan kerajinan gerabah tradisional merupakan upaya untuk melestarikan budaya masa lampau yang kelangsungan hidupnya terancam oleh arus modernisasi. 
Keberhasilan pengembangan kerajinan gerabah tradisional secara tidak langsung dapat menunjang pembangunan nasional, terutama dalam meningkatkan taraf hidup dan mengurangi pengangguran.

\section{KEPUSTAKAAN}

Gearheait, Philip, 1987. Keindahan pada Benda Keramik. Makalah Diskusi Keramik Kontemporer Indonesia, Jakarta. Dalam Subroto SM. Keramik adalah keramik: Makalah Saresehan Keramik dalam Rangka HUT TVRI Stasiun Yogyakarta.

Heekeren, H.R. van, 1956. The Urn Cemetery at Melolo, East Sumba (Indonesia). Berita Dinas Purbakala No. 3. Djakarta.

Matson, Frederich, R. 1965. Ceramics Ecology and Approach to the Study of the Early Cultures of the Near East. Ceramics and Man. pp. 202 - 217. Aldune Publishing Coampany, Chicago.

Sheppard, Anna D., 1974. Ceramics for the Archaeologists. Carnigie Institution of Washington DC.

Soejono, RP. 1977. Sistem-sistem Penguburan pada Akhir Masa Prasejarah di Bali. Disertasi. Fakultas Sastra, UI, Jakarta.

Soekmono, 1974. 1974. Candi, Fungsi dan Pengertiannya. Disertasi, Fakultas Sastra UI, Jakarta.

Solheim II, W.G.. 1965. The Function of Pottery in South-east Asia : From the Present to the Past. Ceramics and Man pp. 254 - 273. Aldine Publishing Company, Chicago.

Subroto, SM. 1987. Keramik Adalah Keramik: Tinjauan Singkat tentang Desain Keramik. Makalah Sarasehan Keramik dalam Rangka HUT TVRI Stasiun Yogyakarta.

Sugihardi. 1994. Gerabah di Situs Candi Bagong, Wonosobo, Jawa Tengah: Suatu Analisis Pendahuluan Temuan Ekskavasi. Skripsi Fakultas Sastra, UGM, Yogyakarta. 
Sukendar, Haris, 1981. Laporan Penelitian Terjan dan Plawangan Jawa Tengah Tahap $I \& I I$. Berita Penelitian Arkeologi No. 23. Proyek Penelitian Purbakala Departemen P \& K, Jakarta.

Sumijati, As. 1972. Gerabah di Daerah Bantul, Yogyakarta. Skripsi Fakultas Sastra UGM, Yogyakarta.

1980. Mengenal Pembuatan Gerabah Tradisional di Daerah Krajan. Wonokolo. Purworejo. Laporan Penelitian UGM, Yogyakarta.

1985. Tradisi Pembuatan Gerabah Nualela Pulan Lomblem. Flores Timur. Suatu Tradisi Teknologi Masa Bercocok Tanam. PIA III. halaman 845

- 857. Pusat Penelitian Arkeologi Nasional, Jakarta.

1994. Gerabah Prasejarah dari Liang Bua, Melolo, dan Lewoleba Tinjauan Aspek Teknologi dan Fungsi. Disertasi UGM Yogyakarta.

Surya Helmi. 1983. Gerabah Sambisari : Suatu Analisis dan Perkiraan Fungsinya. Skripsi Fakultas Sastra UGM, Yogyakarta. 